\title{
Testicular Cancer Clinical TNM Finding v8
}

National Cancer Institute

\section{Source}

National Cancer Institute. Testicular Cancer Clinical TNM Finding v8. NCI Thesaurus.

Code C140187.

A clinical finding about one or more characteristics of testicular cancer, following the rules of the TNM AJCC v8 classification system. 